\title{
Roma in Europe: Human Rights or Humans Out of
}

\section{Sight?}

\author{
Jason R. Young
}

\begin{abstract}
Europe is confronted by a painful paradox; while the idea of 'Europe' conceptualizes the European Union as a champion of liberal democracy, human rights and equality, the position of the Roma clashes with this vision. This paper looks at human rights and exclusion in Europe with specific emphasis on the Roma ethnic minority and argues that prevalent anti-Roma discrimination in both Western and Central- Eastern Europe holds larger ramifications than merely the Roma's constant position of alien, or "despised outsider". The power of discrimination, popular culture and opinion in marginalizing the Roma effectively limits their equal exercise of civil, political, and human rights. The Roma therefore represent tangible limits to the ideas intertwined with European integration. It is argued that the unwillingness to address the issue of Roma exclusion on the local level within specific countries possesses the effect of creating a two-tier citizenship regime that possess the capacity for unraveling the social and intellectual aims of the European Project. Social, legal, and actual exclusion of the Roma therefore holds significant ramifications for social policy within an enlarging EU. The paper presents popular depictions of the Roma and illustrates the pervasive power of exclusion by examining events such as the 1993 Czech citizenship law; the 1999 construction (and subsequent debate over the dismantling) of a wall around Roma apartments in the Czech town of Ústi nad Labem, widespread use of physical violence and intimidation to discourage Roma settlement and racism in Central and Eastern Europe. These events suggest that the pan-European "identity" is far from constructed and that systematic and fundamental change in attitudes towards among elites and society at large and representations of the Roma is essential if the EU's enlargement is to expand the protection of Human Rights on an equal footing throughout Europe for the Roma. Combating historical representations constructed by social and political elites of the groups such as the Roma as an other is of paramount importance if the Roma, and other ethnic minorities, are to be included as equal stakeholders in an enlarged Europe.
\end{abstract}




\section{Introduction}

Daniel Livermore writes, "the ideas of good citizenship and loyalty to the state have gradually become identified with the cultures and traditions of the majorities [within the nation-state]" (1994:10). Livermore raises important questions about the present political and social construction of Europe. They are particularly relevant for postsocialist Central and Eastern Europe (CEE) as this region has revealed that cultural nationalism based upon an ethnic concept of the nation-state remains a driving force (Gheorghe and Acton, 2001: 54). The collapse of communist rule released powerful sentiments of historical injustices and drives to reconstitute cultural identities as sovereign nation-states. This was strikingly apparent within CEE where East and West Germany reunified, while Czechoslovakia voted itself out of existence, creating separate Czech and Slovak states and Yugoslavia fractured violently along ethnic lines. This period reflects in a sense, competing narratives of national emancipation/liberation and of the 'return to Europe'.

In the present era of European integration this raises not only questions about the processes of political transformation in CEE, but also about the construction of “European” as an identity. Ian Hancock writes, “European isn’t a nationality or an ethnicity; Europeans are composed of a multitude of these” (2002:77), and yet, within Europe there is both a multitude of nationalities and ethnicities, in light of ethnic nationalism whose "European-ness" is questioned and even whose presence in Europe, broadly defined, is contested. The reorganization of space in Europe, as it moves closer to political harmonization, and perhaps even foreshadowing the decline of the nation-state, has placed increased emphasis on answering the question what is European-ness and 
unEuropean-ness? This is especially relevant for Eastern Europe, where nationalism has redrawn the lines of who does and does not belong in the national polity.

Despite official pronouncements and discourses of European liberalism, tolerance and multiculturalism, in practice, Europe still excludes outsiders. These outsiders are not however confined to new immigrants originating from outside of "Europe,”; an ethnic and cultural group who have long inhabited Europe, the Romani people (or the Gypsies) have experienced centuries of systematic exclusion and define the threshold between inclusion and exclusion in Europe. In 2000, a preparatory conference in CEE for the World Conference on Racism in 2000 noted, "the Roma remained the least integrated and most persecuted people in Europe” (Council of Europe, 2004: 169). In this article I use the Roma in order to highlight the degree to which Europe continues to exclude outsider groups.

Inclusion and exclusion continues to rest firmly within the framework of nationality and the nation-state. Likewise, the sanctions contained within European Union and Community law for exclusion based on xenophobia, racism, or intolerance fall under the jurisdiction of member-states, which as the article will show, are in fact the offenders, to enforce (Spencer, 1995: 128-135). While European citizenship, in the EU sense provides for a symbolic citizenship that complements rather than replaces citizenship in the member-states, it does not impose an overriding citizenship.

\section{Being Roma and being European: mutually exclusive identities?}

Assertions of Roma identity and rights have often faced a violent response in postsocialist Europe where the re-assertion of national identities increasingly demand 
minorities assimilate into the host society or submit to the cultural and linguistic supremacy of the ethnic majority. Michael Ignatieff asserts “As a political doctrine, nationalism is the belief that the world's peoples are divided into nations, and that each of these nations has the right to self-determination, either as self-governing within existing nation-states or as nation-states of their own” (1994: 5). The expression of Roma identity captured fears among some sectors that the "national" identity and the national polity renewed or reemerging in the post-socialist period is imperiled by the expansion of minority rights and cultures (Tevzadze, 1994: 438). More important, with respect to the Roma, were fears voiced by some Czech and Slovak leaders that international recognition of the new ethnically defined Republics was imperiled by the potential for association of their national identities with Roma culture, which were viewed as backward; this acerbated efforts to exclude the Roma from Czech and Slovak societies in the sense of formal as well as practically citizenship. This comes in light of discourses that emphasized the backwardness of Central and Eastern Europe as a result of the Communist experience, and fears of being viewed as second-class Europeans in light of bids to 'return to Europe'. This is perhaps one of the most acute examples of ethnicity and cultural based identity politics in the 'New Europe'. Dov Ronen provides a bleak interpretation of the re-emergence of the politics of national cultures in CEE, arguing, “[n]ationalism has not only come to rival democracy [in CEE]; nationalist manifestations have come to threaten democracy" (1994: 479).

Europe is confronted by a painful paradox; while many like to see the European Union as a champion of liberal democracy, human rights and equality, the continued marginalization of the Roma -Gypsies- as well as other ethnic communities, both 
Diasporas and regional, clash with this vision. The nation-state as the unit of primary identification is far more important than many would like to acknowledge, and rather then entering a period of decline, in CEE, the nation-state is enjoying a renaissance. In essence, the ideals of European citizenship take a back seat to the formation of the nationstate in so far as citizenship regimes reflect core issues of sovereignty (See for instance Oommen, 1997). While European citizenship complements national citizenship it does not trump the right of the national polity - through national legislation - to decide the criteria for determining citizenship and political participation as well as the extension of its rights (Spencer, 1995: 129). More importantly, minorities, such as the Roma, provide convenient outlets for domestic frustrations within the impact of political and economic instability within CEECs (Evans \& Need, 2002: 656, 675).

\section{The space of other in Europe: The Roma}

On the eve of the dramatic changes which swept throughout Central and Eastern Europe after the collapse of communism in 1989, a young Roma woman paused to allow her photograph to be taken in front of the dilapidated shack, cobbled together from pieces of corrugated tin, wood and fabric in which she and her family lived on the margins of a Bosnian town. Her remark, "let the whole world see from your book how we Gypsies live. Like we weren't people at all. There's no work and no home for us, like there is for others,” speaks as forcibly about the isolation of Europe's approximately 10 million Roma on the margins of city and societies in 1989 as it does in 2006 (Tomasevic, 1988: 133). The Roma have been confined physically, politically and socially to the margins of 
many European societies by the status of undesirable or "despised outsider"(Barany 2002: 2).

Ghettos, lack of adequate education, healthcare, housing, high unemployment, racism, ethnic violence, state indifference or active discrimination are all features of Roma life in many countries (Cahn, 2002: 48). The Europe spoken of in the Helsinki Final Act, the Convention on Human Rights, in the Framework on Minority Rights and in the rhetoric of European integration to a large degree is not the Europe experienced by most Roma. Former Czech President Václav Havel remarked that the treatment of the Roma is a "litmus test of civil society"; it is a test Europe is thus far struggling to pass (Fawn, 2001:1195). The Roma face a deep cycle of systemic racism, poverty, and even statelessness. Their case is not merely that of an ethnic minority struggling to define its place in a rapidly changing Europe; the case of the Roma speaks about the forces of integration, identity and citizenship, social exclusion and equality; it suggests that minorities exercise very little power in the process of shaping European integration, beyond acting as a moral signpost; that is unless they seek and obtain separate nationstates. Indeed, it was not until the influx of large numbers of Roma seeking asylum in EC/EU countries that Western Europe took serious notice of the condition of the Roma in CEE. The Roma as a subject confront the territorial, cultural and legal boundaries of the nation-state as an institution and the intellectual and social ideals of an enlarged common European home. The problem posed by Europe's 'Gypsies', is not, how will the European Union find a home for the Gypsies, but rather, can the European Union protect the rights of other cultures and ethnic minorities, especially small groups within specific nations as well as throughout an increasingly larger 'Europe'. 
While Article 8 of the Treaty on European Union (TEU) confers equal European citizenship on member-states' nationals, Alvaro Gil-Robles, the European Commissioner for Human Rights in his Report for 2003 asks a timely, but uncomfortable question: whether it is possible to be a non-citizen of the Union? (Council of Europe, 2004: 28). The Roma are effectively non-citizens, their rights in practice are not equal to those of other national and European citizens. Racism and prejudice relegate them to the status of second or third class citizen, often below that of ethnic and culturally distinct im/migrants such as the Turkish Gastarbeiter. They are rejected by mainstream societies that seek to either remove their culture through assimilation, or push it far enough to the margins that it is excluded (European Roma Rights Center, Nov, 2005: 31). Ethnic groups such as the Roma, that is a group recognized as a distinct group on the basis of shared national/ linguistic/ cultural, religious, ancestral traditions or origins face negative pressures in identifying themselves as a ethnic minority or promoting that identity. This is especially the case in CEE as a result of the degree to which nationality and ethnicity are politically charged and the emphasis on either assimilation or on simply not permitting competing identities. David Mayall writes, “[t]he struggle for the recognition of ethnic status [by the Gypsies] has largely been achieved within the specialist academic community engaged in Gypsy studies, but only small headway has been made outside this limited field” (Mayall, 2004:243). What is clear in much of the literature is that the transnational similarities between public perceptions and representations of the Roma are striking.

The article has two deeply interconnected themes, the first is the link between social and physical marginalization and isolation of the Roma (the boundaries between cultures), and the second, is discourses of power which employ narratives of biological, 
social, or ethnic otherness as legitimating mechanisms to enforce the limits of the first (narratives defining the impermeability of those boundaries). Modernity, both through connections of physical space and as discourses of social order highlight some of the processes of Roma exclusion. Peter Vermeersch notes, “[t]he identification betweens social behavior and ethnic identity can easily be maximized in public discourse and can lead to support a ‘discourse of otherness'. For example, when speaking of Romani policy, certain politicians have attributed problems of social disadvantage to a reified notion of the 'Romani way of life’” (2003: 898). Few reject the isolation of criminals from society for societies protection, but what of an ethnic identity that is criminalized? The "stigmatization” of Gypsy as an identity through hostile discourses drives much of the difficulty between Gypsy and non-Gypsy communities. There are plenty of grey areas between these two themes, but nonetheless, they define the mechanisms and the methodology of exclusion.

\section{The perceptual basis for discrimination}

Joseph Agassi and Norbert Elias have observed that Modernity, or the process of promoting and maintaining the new social order — broadly defined as civilizing society and changing social and power relations with space- has placed unprecedented power in the hands of the nation-state to regulate and remove the "chaotic" from society (Elias, 1978; Agassi, 1996: 385-401; Bancroft, 2005:51). Modernity links these interconnected themes into a series of processes which modernize, categorize and constitute subjects as fields or objects of knowledge (Foucault, 1983). If civil society and inclusion is thought of as a series of processes through which one becomes accepted as belonging within a 
society then this status of other, or outsider is likewise a series of processes meant to exclude (Penninx et al, 2004:141). The manufacture of this discourse has its roots in the Enlightenment quest for unity, coherence and community that constructed and regularized the divisions of labour and race as well as the emergence of the nation-state as an ethnically and culturally homogenous homeland of a particular group (Livermore, 1994:10; Mayall, 2004:101, 104-105). The race for empire among the European powers and the emerging 'science' of Race provided the intellectual and moral mandate for the European mission civilisatrice. More importantly, it provided the tools to categorize the newly acquired colonial possessions as lesser subjects along the basis of skin colour and race; Modernity provided the methodology to construct the racial and social 'other'.

Ann Stoler observes social and political power narratives of those from a group with subordinate social status not only manifest in discourses of order but also in ideas of racial and national purity and co-committal ideas of racial and class inferiority (Stoler,1995; Sokolova, 2002: especially chapters 4 and 10). Evidence illustrating this type of thought is readily available, for example in the history of France's colonial empire in Southeast Asia. French administrators, traders and church officials alike viewed and treated the Vietnamese as "an inferior, child like race, ideally suited for a life of hard work for low wages”; work that was deemed beneath educated, literate, Christian Europeans (Moss, 1998:14). This separation of labour (class), also equated a separation of power based on assumptions about the Vietnamese's nature, (order) but also their inferiority and inequality to exercise the same rights as white Europeans (race). Similar attitudes towards ethnic or cultural others can be tracked in other civilizing missions; for example American 'Manifest Destiny' and the political debate on Philippine self- 
governance and Filipino acquisition of American citizenship following the annexation of the Philippine Islands from Spain. Senator Henry Cabot Lodge summed up the difference between 'dark skinned savages' and cultured whites on the floor of the United States Senate, commenting, "Whither they are fit to govern themselves, they are not fit to govern us” (Lasch, 1958: 327). The construction of minorities as the 'others', and as groups with lesser social value or rights plays out in discourses that reinforce those distinctions through narratives of difference. These are distinct features of cultural domination at work, which label and categorize the weaknesses or failings of other cultures. The defining of opposing or coexistent cultures and their reduction of status to other legitimates the exercise of policies that exclude them from the body politic.

The Roma, seen as incapable of belonging, and therefore displaying loyalty to the state, are reduced to the status of other, or alien culture. This not only positions them beneath the lowest rung on the social-economic ladder; it utilizes a discursive strategy that presents the Roma as either unwilling or incapable of participating in society; at the extreme it situates them as threatening to national and cultural survival (Stoler, 1996:9). This social construction of the Roma as dangerous to national unity or cultural coherence provides ontological justification for repression and exclusion of the Roma in the name of cultural and national survival.

Two key observations about the processes of modernity become clear; that it is spatially oriented, and that is hierarchically organized along lines of productivity or perceived social value. Territory, or spatial relationships therefore are key aspects in relationship between the state and political and legal rights. Geography, social space, and the use of space as power are therefore essential aspects of modernity. Space, however, is 
more than geography in terms of belonging and power; modernity also fixes the boundaries of social space, establishing and reinforcing the divisions between class and political power and between ideas of national space and ethnic space (Foucault, 1980:6869). The power dynamic establishes and reinforces social and political hierarchies of power by reducing the status of other groups and therefore their right to geographic and social inclusion (Mayall, 2004:12).

\section{The Roma as a subject: some attitudes}

Why is discrimination and marginalization accepted and even justified by a large majority of national population? How is it that governments and the state, thought of by modern human rights regimes as having a responsibility to protect its citizens, have allowed or even designed the structures of systematic exclusion and been so hesitant or unwilling to dismantle them? The roots of discrimination targeting the Roma are closely connected with discourses of what the Roma have been made to represent; it also shares a great deal in common with the treatment of minorities in general; the social status of other and the contest for dominance and space (Ringold, 2004: Vii).

The Roma have been described as Europe's other unwanted population, and the discourse of otherness surrounding the Roma portrays them as anti-modern, rootless, criminal and often as dangerous to the progress and cohesiveness of society.

One Hungarian poll, conducted in the 1970's revealed that approximately a quarter of the Hungarian population viewed the gypsies as "lazy, immoral and prone to criminal behavior", while another showed that most viewed the Roma as "work-shy” and "welfare parasites who receive too many social benefits” (Helsinki Watch, 1993:40). A series of recent inquiries into Czech attitudes revealed that many feel the Roma's isolation is of 
their own making, having squandered government and societal support (Fawn, 2001: 1196). Surveys in post-socialist Hungary reveal not much has changed, with attitudes towards the Roma ranging from indifference to outright hostility; in a letter to the editor of a local paper, one Hungarian opined:

I cannot comprehend, even if you're a liberal how could you always and in every case take the gypsies' side? ... That everyone harms the poor gypsy, from the government to the local council,that I've heard often from you, but not the reason everyone hates them! They cannot live like normal European people, though they had twenty-five years to thirty years to become humanized under the communists. Nobody forbade them from working and learning. But they steal and beg instead from childhood on. They teach their children to cheat.... And don't tell me its poverty that made them do it because they are not poor. They have money for everything from food to taxis.... (Human Rights Watch, 1993: 47-48)

A 1999 UNDP public opinion poll in Bulgaria reveal that $78 \%$ of the population indicated they did not want Roma as neighbours, ranking the Roma lower then former prisoners in terms of preference of neighbours (Ringold, 2000: 8). A 1991 survey in three CEE countries revealed 78\% percent of respondents held definitively negative attitudes towards the Roma (Barany, 1994: 329). A report by the human rights group Helsinki Watch, notes that roughly $60 \%$ of the Male prison population in Hungary are Gypsies, making the rate of Gypsy imprisonment 12 times the national average (Quoted in The Economist May 12-18, 2001: 30). Similarly, exclusionary social thought can be found in Western, liberal Europe as well; in Britain, a member of the township of Sheffield's Council, in the UK remarked after a debate about regulating camping sites, “ I wish you would stop calling them gypsies...they're cannibals, they're parasites on society" (Mayall, 2004: 261). Such sentiments are telling important, as law has historically been one the key tools used to both legitimate and exercise control over the assimilation and exclusion of the Roma. Recent Czech government positions have defined Romani 
interaction as a one-way process: "Integration, then, is understood to mean the Romani community's full-scale incorporation into [Czech] society while preserving most of the cultural specificities... and which it wishes to adhere to so long as theses distinctive features are not at variance with the laws of the Czech Republic.”(Vermeersch, 2003: 893). Rather then ensuring human rights or group protection, government and social efforts have focused at keeping the Gypsies out of sight.

Denied inclusion in the social and educational fabric of Czechoslovak society in the post-war reconstituted Czechoslovak state, popular perceptions of the Roma as uncontrollable, distinct and unreliable, and incompatible with Czech and Slovak culture and identity ensured that the Roma were excluded from the start. The 1958 Czechoslovak law outlawing nomads represented similar perceptions of the Gypsies as social parasites or undesirable nomads, "who wander from place to place, even if they are permanently registered is some village, and avoid honest work or support themselves through dishonest activities” (Solkova, 2002:8). Dr. H. Arnold, writing around the same time period in the Gypsy Lore Society's magazine in Britain in 1961 opined, "the essential Gypsy nature is due to a hereditary characteristic which determines whether a person is in behavior a Gypsy.”(Quoted in Mayall, 2004:133). This suggested that illegal or immoral behavior is a distinctive feature of Gypsy identity. Similar sentiments such as those voiced by Jozef Pacai, the mayor of Medzev in Eastern Slovakia, can be found in posttransition Eastern Europe who remarked, "I am no racist...But some Gypsies you would have to shoot” because of their nature (Vermeersch, 2003: 893).

What is presented here is a depiction of the Roma as an outsider within their own societies by genetic, social, or cultural practices; the implications however, are far 
reaching. Among many Czechs, surveys have revealed there is a sense that the Roma reject the values of Czech society, or that as a group, they are incompatible with Czech, or European society. Indeed, many continue to view the isolation of the Roma as necessary. One Czech government report observed, “ [The Government] is aware that the majority of the Czech citizens is able and willing to accept Romanies only when they adapt to the majority and assimilate into it” (Vermeersch, 2003: 894). Similar sentiments are discernable in Western Europe, for instance the mayor of Gisors, France remarked that the stopping areas required by the French Besson law (Security Law) should be constructed in a guarded and controlled area outside the town limits in order to keep the “security threat” posed by the Gypsies as far away as possible (European Roma Rights Center, Nov, 2005:95). This 1956 Czechoslovak depiction of the Roma as dark-skinned, unproductive nomads with multiple children and dogs living in caravans devoid of order continues to find remarkable traction throughout present day Europe.

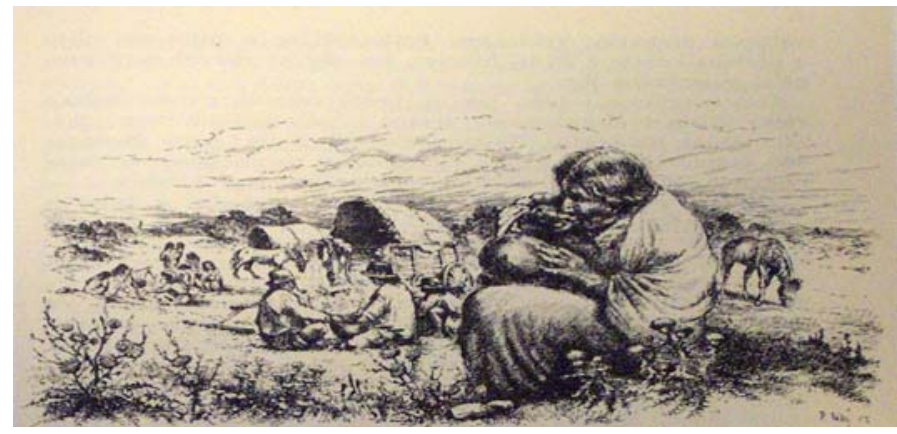

Fig A: Czech Depiction of Traditional Roma life. Note the prominence of the caravans, dark skin and the inevitable dogs. Zdeêka Jamnická-Smerglová, Dêjiny nas^ich Cikánú (Prague: Orbis, 1955. 59)

This discourse of the Gypsy as physical representations of social disorder perpetuates the conditions that magnify their exclusion as a source of disorder. Discriminated against as unwilling to participate in meaningful employment and joining sedentary life, prevented 
by racism from obtaining meaningful employment, or prevented by lack of educational opportunities from integrating or participating on a equal basis, they are confined to a vicious circle of poverty and exclusion. Racism and discrimination has created in effect a second-tier of citizenship. Indeed, a December 1950 Czechoslovak document reveals that Communist authorities realized that integration of the Roma into communist society was entirely dependent on the willingness of the Czechoslovak population to accept them as belonging (Solkova: 2002: 101). In spite of Czechoslovakia’s Communist governments efforts to force the settlement of the Roma and assimilate it into communist society, popular perceptions - ironically those produced by the regime itself - effectively created Roma ghettos in cities and towns that served to reinforce Gypsy as an identity and cut off the Roma population from the services and opportunities necessary to shed the traits viewed by the regime and society as anti-modern and socially disruptive. In other countries, such as France, laws have been passed which require 'travelers' (almost exclusively Gypsies) to possess circulation documents, and the permission of the police to move about or set up camp. The absence of either can result in criminal sanction (European Roma Rights Center, Nov, 2005: 61). One of the core features of discrimination is therefore the criminalization and depiction of the Roma as not belonging, nor capable of belonging, making them whoever the writer or speaker wants them to be, whether that be an ethnic minority, a criminal group, social vagrants, or a race (Mayall, 2004:3). 


\section{Modernity, the city, and exclusion}

If it is accepted that one of the key aspects of modernity is the intertwining of power with physical geography through the social and physical transformation of space from rural, unproductive and uncivilized to urban, orderly and modern; then the rise of the city as a feature of modernity provides and key example between the rights, space and power linkages connected with modernity. In a social capacity, the city provides a framework to examine the relationship between space, power, inclusion and exclusion. In order to exercise equal participation, the Roma must assimilate and become Czech, Hungarian, French etc, and no aspect of Roma culture is seen as compatible with modern living. For the Roma, the struggle for space, and thus inclusion, plays out on the edges of the city; the degree of spatial separation between the Roma and non-Roma community has a direct connection with levels of Roma prosperity or poverty, access to equal services and therefore inclusion and exclusion (Ringold, 2004: 62).

As a social institution based on cohesiveness and continuity, the city, as a territorial and social project, allowed urban communities to survive war, religious and political upheavals (Friedrichs, 1995). Modernity's isolating and removal of the 'chaotic' from society makes the urban city a dividing line between 'modern' society and uncivilized elements which threaten social cohesion; or keeping out the other. Thinking about exclusion through the framework of the city works as effectively for $18^{\text {th }}$ century Europe as it does for the twentieth, to evaluate the prominence of Roma settlements on the outsides - or margins- of towns, and ghettos within the urban environment in CEE and Western Europe. 
If we return briefly to Ann Stoler, who argued that socially engineered and constructed values play an important role in providing the benchmarks against which claims of citizenship, property rights and public value are measured, then within the urban city the ability of the Roma to access, remain within, and exercise property ownership and access to public services reveals the depths of Roma marginalization (Stoler, 1995:7-8). Residential segregation is not a new experience for the Roma, even those who have settled into sedentary life styles. In Central and Eastern Europe, the roots of segregation predate the socialist era; despite one of the main social projects of the CEE communist regimes being the denial of ethnicity and the effort to forge new socialist societies, segregation was deepened by the efforts of the Communist regimes to control the Gypsy population therefore had distinct spatial aspects. The Czechoslovak Communist party identified the nomadic nature of the Gypsy population - to many extents a direct result of social ostracism - as the major barrier to successfully forging a new society. The Czechoslovak Communist government attempted to resolve the 'Gypsy question', by removing, legally, the status of Gypsy through the passage of the "law about permanent settlement of nomadic persons”. Modernity is deeply connected with this effort, in that it was the first law not to use the term Gypsy, or any other ethnic distinguishers, instead adopted the language of modernity, and the goal of settling unproductive citizens into productive citizens. This law was part of a discursive strategy aimed at removing the 'Gypsy' as an identity and as a legitimate subject.

Enforcing state authority required extending its spatial control to citizens outside of its normal power base. Spatial control was a key aspect, and state agencies were ordered to "liquidate gypsy camps and ghettos in order to get rid of all sources of gypsy isolation" 
and bring the anti-modern life style of the Gypsy into the modern environment of the city (Solkova, 2002:106). A series of raids by local police and security services were efforts to end the "backwardness and the incorrect way of life of citizens of Gypsy origin in [Czechoslovakia], to increase their standard of living and to reeducate them into being dignified citizens of our socialist society” (Solkova, 2002:112). Bringing a 'dignified' existence to the Gypsies meant the taking of a census, but discrimination was readily perceptible with local police units cutting off the wheels of caravans, and confiscating Gypsy groups horses in order to force their conversion to sedentary life:

They came in the middle of the night. It was cold. They woke everybody up. Adults and children. And started to count everybody. They took horses, our biggest friends and helpers. And cut wheels off the wagon - calling us black gobs...(Solkova, 2002: 118)

By virtue of being where they were the night of the raid, Roma groups where made members of whichever town they were closest to; those towns, in turn, inherited the responsibility to clothe, feed, and educate them in order to transform their lifestyle and identity (Solkova:2002:120). The biases against Gypsy culture are accessible in directives from the national party authority to local levels to teach the Roma how to live in apartments and modern society (Solkova, 2002:104). Local resistance, and difficulty assimilating the Gypsies into local communities was two fold; local communities refused or resisted their integration, and Gypsies themselves, refused to accept their reduction to the non-status ascribed by the state.

Vera Solkova advanced an interesting argument, which explains in some ways the post-1989 experiences of the Roma in Central Europe; their reduction as a subject or group with an ethnic right to inclusion and participation in civil society and reduction to 'social deviant' under communism built upon existing prejudices. This depiction, and the 
all to frequent criminalization of their lifestyle and culture removed their entitlement to recognition and protection as participants in civil society by conferred upon them the status of criminal (Solkova, 2002:114). The sudden changes in Europe only served to reinforce those perceptions. More so, the often physical difference between the Gypsies and their Czech and Slovak neighbours ensured that the Gypsy community was in effect pushed by popular opinion and local particularity into a Ghetto either within the city, or that the boundaries of the city proper shifted in ways which pushed the Gypsy population to the city's margins. The lack of opportunities within cities were reinforced by educational differences; where Gypsy children were placed into special remedial classes in schools, which in effect closed off higher education, dooming successive generations of Roma to menial labour jobs and increased social isolation (Solkova, 2002: 222).

Regime efforts to assimilate the Roma into Czechoslovak were the victim of a double-edged sword, the first being the artificial nature of the communities the communist regimes attempted to create through forcible integrating of the Roma into towns. The second, was the all to successful campaign to describe the Roma as 'asocial', or social parasites and the failure of the regime to enforce a true lack of distinction, which created ghettos, second class educational and employment options, and essential reinforced the difference Czechoslovak society intimately felt between themselves and the Gypsies. István Pogány observes, “[i]t is widely recognized that Gypsies, or Roma, have been routinely denied basic rights and that they have been treated less favourably than non-Roma by bureaucracies, courts and police in much of Central and Eastern Europe”(Pogany, 2004:13). 
Communist Europe was not alone in its treatment of the Roma as social deviants or a disruptive force to social cohesion. In both Britain, and France, the Gypsy community has not fared well. Take for example, the use of city bylaws to force Roma who own the property they live on to move. In the town of Merignac in France, the local mayor used article 9 of the security law. which relates to public order, to evict Gypsy families. It is notable that only Gypsy families were forced out and subjected to having their homes destroyed (European Roma Rights Center, Nov, 2005:128). The courts, when asked to review or intervene have frequently ruled in favour of the municipalities, or declined to hear the cases on 'procedural grounds'. The tone of anti-Gypsy sentiments is readily accessible through the comments of elites. Take for instance, the following from the Prefect of Vaucluse:

You can ask my former colleagues... I have no particular tenderness for those people. They live at our expense, from pillage too, everyone knows it. When they invade a piece of land, believe me, I am always ready to use all means to expel them. But there is a law that imposes a halting area in each commune of more then 500 residents, and it is necessary to respect it.... Don't worry, I know how to behave with respect to this subject (European Roma Rights Center, Nov 2005: 32-33).

Institutional expressions of anti-Gypsy public sentiment become institutionalized harassment that chases Gypsy groups from one community to the next, often with the stated goal of driving the Gypsy out of the country. In the Czech Republic, following the 'Velvet divorce', anti-Gypsy sentiment took on a far more invasive form, the outright denial of citizenship. Following the break up of the country, a new citizenship law was drafted which conferred “Czech” citizenship on those who where considered Czech under the 1969 citizenship law, and deemed all others as aliens. Ethno-politics and ethnonationalism were key elements of the mix that drafted the law in order to deny Czech citizenship to "Slovaks" in advance of an anticipated wave of economic migration from 
the poorer Slovak Republic (CSCE, 1994:22). A further aspect of the Czech law was its prohibition on eligibility for citizenship to those with criminal records within the previous five years. On the eve of its passage, numerous local police forces raided Gypsy ghettos to ensure that as many Roma as possible possessed criminal records and thus would be ineligible for citizenship. Czech officials have admitted that nearly all those excluded under the Czech citizenship law, were in reality, Roma; wanted by neither the Slovak nor Czech Republics effectively found themselves stateless and thus citizenship less (CSCE, 1994: 26-27). Slovak Premier Vladimir Meciar, argued in a September, 1993 speech that he considered it, "necessary to curtail the 'extended reproduction of the socially inadaptable and mentally backward population", he was referring to the Roma, An "official translation" of his speech was released shortly after in efforts to assuage Western European outrage to his remarks; that translation asserts,

They [the gypsies] should be perceived as a problem as a problem group that is growing in size... This means if we do not deal with them now, they will deal with us later.... Another thing we have to consider is extended reproduction of socially inadequate population. [sic] (Crowe, 1991: 66).

Meciar's comments were foreshadowing of deepening exclusion of the Roma from Slovak society. Within the immediate period of the collapse of communism and the 'Velvet Divorce', Roma settlements in Slovakia increased from 278 in 1988, to 591 in 1998 (Ringold, 2004: 61). In the Czech Republic, local elites and town governments sought central government assistance to "repatriate "undesirables” to Slovakia” (Barany, 1994: 337). Fears of association between the national identity and Gypsy identity manifested in as efforts to remove the Roma: “[a] Gypsy will not work, he wants to wander, steal and live his own life. Gypsies are a terrible advertisement for us. Foreign 
tourists take pictures of the gypsy gangs, their camps and wagons -soon we will be known abroad as the nation (národ) of Gypsies. (Solkova, 2002: 91).

Europe’s Roma find themselves economical, socially, and financially inhibited from asserting rights on par with ethnic majorities. The city, as a space for observing and evaluating Roma inclusion and exclusion, as the Slovak, Czech, and French examples reveal is an ideal site. Perhaps, the most telling example of the Roma's place in European society comes from the Czech town of Ústi nad Labem, and the construction by local residents of a sixty meter long, two meter high reinforced concrete wall with three gates locked nightly (creating in effect a detention camp) and patrolled by uniformed police around the apartment block housing mostly Gypsies in October of 1999 (Council of Europe, 2004 :169). The construction of Gypsy identity as criminal and dangerous found physical expression in the efforts of local residents, unable to physically remove the residents, to isolate them, in effect building a physical ghetto where a cultural economic and social ghetto already existed (Solkova, 2002: 3-5). Even within the core of the city, where communist authorities had previously forced the Roma's physically inclusion, in reality, social exclusion in the form of a ghetto exists.

Similar circumstances can be found in the Slovak Republic, where a substantial portion of the Roma have been forced to live on the outskirts of towns or continue to face discrimination such as curfews either directly sanctioned or tacitly ignored by government officials (Barany, 1994: 338-339). Forced inclusion by law and legislation by the EU or national governments will only have the effect of continuing to perpetuate Roma exclusion and xenophobia as Ústi nad Labem illustrates at the worst, and at best, will only maintain the status quo. There are signs that positive change is being made, but 
it all too frequently comes as a result of incidents such as Ústi nad Labem (which was extremely embarrassing for the Czech national government) or the drowning death of a young Roma chased by skinheads into a river in 2003. Paul Polansky captured the attitudes that led to that death succinctly in his poem, "The River killed my brother":

They weren't skinheads who threw my brother into the river.

They were boys he went to school with...

I ran for help. . I didn't have to go very far.

Two policemen were sitting in a car watching, laughing. (2001:6)

This status of 'other' perhaps speaks most for the plight of the Roma than any of the many terms commonly used to describe them, Tsigani, Roma, Gypsy, Gypsy-Traveller or any permutation thereof. The Roma have been traditionally viewed as a problem, as barriers to progress and modernization and thereby subjected to wide reaching efforts by state authorities at assimilation and elimination (Solkova, 2002:10). In the aftermath of the demolition of the Gypsy wall in Ústi nad Labem came two separate comments that reveal the depth of animosity towards the Gypsies, as well as the strength of prejudice. The first, is closely linked with the earlier illustrated processes of modernity, and connects the economic dislocation experienced by many Czechs during the transition to market economies with a physical target, "Everything, whether it is criminality, drugs, whatever comes to your mind was first started by the Roma”. The 'Wall' itself illustrates the second aspect, which is the impermeability of borders between social spaces. One Czech woman asked, “Why can't the Roma behave as decently as we do?” (Solkova, 2002 :5-6). Race, class and social characteristics are intrinsically linked in the production of a divide, which positions the racialized 'other' in opposition to the mainstream (Stoler, 1995:22). The politics of exclusion in CEE can be thought of as a two-tier process with respect to the Roma: the first finds its basis within an agenda located in the processes of 
modernity, understood through economic and social aesthetics, in that 'white' society ascribes to itself the social values and ideal its holds at the highest level, whereas 'dark', or 'black' society are represented as exhibiting criminality, backwardness and social practices rejected or held in contempt by the majority population. Concurrently, a Western European modernity project is taking place, shaping Eastern Europe as an object, in the context of which CEECs attempt to emphasize their modern-ness, or European-ness. (Dunn, 1995; Kuus, 2004:482). Geopolitically, the implosion of communist regimes shifted the borders, real and imagined for Europe, creating new spatial orientations and a new 'East' (Dingsdale, 2001:5, 11). At the same time that this process unfolded, western European states began enacting a series of legislative acts, and acts by effect, which aimed to limit the real or perceived influx of eastern Europeans, particularly Roma to Western Europe, to take advantage of the social security net. In effect, the continued existence of these laws, and laws that affect Roma exclusion (or other ethnic minorities) reveals the tension between 'old Europe' and a 'New' Europe. The full rights of EU citizenship cannot be denied to a substantial number of citizens, based on their ethnicity and yet be still thought of as citizenship, in its full sense (Council of Europe, 2004:29). In an article titled, “the coming Hordes" the January 15 edition of The Economist magazine captured the position of outsider that the Roma hold. (The Economist, January 15, 2005:) The Roma exist on the margins described in the opening to this paper and as Vaclav Havel noted, they are indeed a litmus test for the Human rights regime. The Roma are the quintessential outsiders; they are often seen as a social problem to be solved not through inclusion, but rather regulated exclusion (Pogany, 2004:51). Massive economic and social dislocation, combined with historical 
prejudice have created an environment where even in geographies where the Roma population possess formal citizenship- with all the formal entitlements and protections- in practice they are subjected to a 'different' type of citizenship which denies them the basic rights accorded to other citizens (Bancroft, 2005:32). For CEE, the construction of internal narratives of ethnic state and national identity place ethnic minorities, despite legislation or official government positions at a disadvantage. For CEE, treated as a “subject” by Europe proper, in need of western European expertise, institutions and structures in order to become fully European, the effort to retain national identities finds a direct tension with integration. Ironically, perhaps, is that integration itself, is in tension between national identities and supra- nationalism. The position of ethnic minorities in CEE, and in Europe at large continues to remain tenuous as integration increasingly reframes discourses of Europeanness and ethnic and territorial claims of what is European and not European back to the center of the debate on political integration especially in light of the debate on Turkish accession. What separates a Czech or Pole from a Romanian, a Russian, or a Latvian and what defines a "European” from a "nonEuropean”? For Central Europe, and the Roma, discourses that define the geographic and geopolitical space, as well as the nations and the peoples who inhabit it as an "other" places the continued exclusion and marginalization of the Roma in a position of constant relevance for evaluating European citizenship and integration. 


\section{Bibliography}

Agassi, Joseph. "The contemporary role of historians of science and technology” Protosoziologie 8 (1996): 385-401.

Bancroft, Angus. Roma and Gypsy-Travellers in Europe: Modernity, Race, Space and exclusion. Burlington, VT: Ashgate, 2005.

Barany, Zoltan. The East European Gypsies: Regime change, marginality and ethnopolitics. Cambridge: Cambridge University Press, 2002.

"Living on the edge: The East European Roma in Postcommunist politics and societies” Slavic Review 53:2 (Summer, 1994):321-344.

Cahn, Claude. Roma rights: Rights, justice, and strategies for equality. New York: International debate education association, 2002.

Commission on Security and Cooperation in Europe, Implementation of the Helsinki accords: Human rights and democratization in the Czech republic. (September, 1994) Washington DC: Commission on Cooperation and security in Europe, 1994.

Council of Europe, Commissioner for Human Rights; " $4^{\text {th }}$ annual report; January to December 2003 to the Committee of Ministers and the Parliamentary assemble" 15 December 2004. Strausbourg: Council of Europe, 2004.

Dingsdale, Alan. Mapping Modernities: Geographies of Central and Eastern Europe, 1920-2000. New York: Routledge, 2001.

Dunn, Elizabeth C. "Standards and person-making in east-central Europe" in Global Assemblages: Technology, Politics and Ethics as Anthropological Problems, Oxford: Blackwell Publishing, 2005. Pp.173-193.

Elias, Norbert. The civilizing process: the development of manners. New York: Urizen Books, 1978.

European Roma Rights Center, "Always somewhere else: Anti-Gypsyism in France”. Country reports series, No 15. (Nov, 2005) Budapest: European Roma Rights center, 2005.

Evan, Geoffrey and Ariana Need. "Explaining Ethnic polarization over attitudes towards minority rights Eastern Europe: A multilevel analysis" Social Science Research 31(2002): 653-680. 
Foucault, Michel."The Culture of the self “ University of California-Berkeley Regents Lecture. April 12 and 19, 1983.

Power/Knowledge: elected interviews and other writings, 1972-1977. Brighton: Harvester Press, 1980.

Fawn, Rick. "Czech attitudes towards the Roma: 'Expecting more from Havel's country’?” Europe-Asia Studies 53:8 (Dec, 2001). 1193-1219.

Friedrichs' Christopher R. The early modern city, 1450-1750.A history of urban society in Europe, Vol.1. London: Longman, 1995.

Nicolae Gheorghe \& Thomas Acton, “ Citizens of the world and nowhere: Minority, ethnic and human rights for Roma during the last hurrah of the nation-state.” In Between Past and Future: The Roma of Central and Eastern Europe, Ed, Will Guy. Hertfordshire: University of Hertfordshire Press, 2001.

Hancock, Ian. We are the Romani People (Ame sam e Rromane dzene). Université René Descartes. Centre de recherches tsiganes. Hatfield: University of Hertfordshire Press, 2002.

Helsinki Watch. "Struggling for ethnic identity: The gypsies of Hungary”. New York: Human rights watch, 1993.

Kuus, Merje. "Europe's eastern expansion and the reinscription of otherness in EastCentral Europe” Progress in Human Geography 28:4 (2004): 472-489.

Lasch. Christopher. "The Anti-Imperialists, The Philippines, and the inequality of man." The Journal of Southern History. 24:3(1958): 319-331.

Livermore, Daniel. Ethnic conflict in the New Europe, Queens Centre for International Relations, Martello papers \#10, Kingston: Queens University Press, 1994.

Mayall, David. Gypsy Identities: From Egipcyans and Moon-men to the Ethnic Romany. London: Routledge, 2004.

Moss, George D. Vietnam: An American Ordeal._Upper Saddle River, N.J.: PrenticeHall, 1998, 14.

Penninx, Rinus; et al, Eds, Citizenship in European Cities: immigrants, local politics and integration policies. Burlington VY: Ashgate, 2004

Pogány. István. The Roma Café. London: Pluto Press, 2004

Polansky, Paul. The River killed my brother. Poems of the Czech and Slovak Roma since 1989. San Francisco: Norton Coker/ JEJUNE Publications, 2001 
Ringold, Dena. Roma and the transition in Central and Eastern Europe: Trends and challenges. Washington, DC: The World Bank, 2002.

Roma in an expanding Europe: breaking the poverty cycle. Washington, D.C.: The World Bank, 2004.

Ronen, Dov "On the incompatibility of "nationalism” and "democracy"-Lessons from East Central Europe” History of European Ideas 19:1-3 (1994). 479-484.

Sokolova, Vera. "A Matter of speaking: Racism, gender and social deviance in the politics of the "Gypsy Question” in Communist Czechoslovakia, 1945-1989” Phd. Diss. University of Washington, 2002

Stoler, Ann Laura. Race and the Education of desire: Foucault's History of Sexuality and the colonial order of things. Durham: Duke University Press, 1995.

Vermeersch, Peter. "Ethnic minority identity and movements politics: The case of the Roma in the Czech Republic and Slovakia” Ethnic and Racial Studies 26:5 (Sept, 2003): 879-901.

Tevzadze, Natia. "National identity and national conciosuness" History of European Ideas 19-1-3(1994): 437-440. 